\title{
Empirical Analysis of Carbon Emissions for Land Consolidation Project and Countermeasures for Low carbon
}

\author{
Bao-Ming DONG ${ }^{1}$, Zhao-Wei DONG ${ }^{2}$, Yan-Bin WU ${ }^{3, a,{ }^{*}}$ \\ ${ }^{1}$ College of Business Administration, Hebei University of Economics and Business, \\ Shijiazhuang 050061, China; \\ ${ }^{2}$ Party Committee Office, Hebei University of Economics and Business, \\ Shijiazhuang 050061, China; \\ ${ }^{3}$ College of Management Science and Engineering, Hebei University of Economics and Business, \\ Shijiazhuang 050061, China; \\ a wuyanbin080@163.com
}

Keywords: Carbon emissions, Land consolidation, Land use change, Fossil fuel use.

\begin{abstract}
Since the industrial revolution, land use and land cover changes (LUCC) mostly resulting from human activities have been a significant source of carbon exchange between terrestrial carbon pools and the atmosphere. The effects of LUCC on terrestrial ecosystem carbon storage and their budget has become a focus of scientific research. In this paper, we provide an empirical analysis of carbon emissions for land consolidation projects (LCPs) in Julu and Baixiang Counties, Taihang Piedmont, Hebei Province, China . Based on energy consumption and land use change theory, we use carbon emission inventory methods to analyze the carbon emissions caused by land leveling, irrigation and drainage, road construction, farmland protection and land use changes. The study identifies the effects of land consolidation activities on carbon sources and sinks and presents methods for their calculation. Carbon emissions are estimated for fossil fuel use in the LCP implementation process and for carbon stock changes due to land use conversions in the LCP.
\end{abstract}

\section{Aims and Background}

The global carbon cycle and food security are two key issues in climate change research[1-4]. The combined effects of climate change and land use change influence not only carbon emissions but also grain production[5,6]. Agriculture is a key sector in China, providing food for more than 1.4 billion people from less than 133 million hectares of cultivated land. How to improve grain production and farmers' livelihoods with less carbon emissions will be a major concern in China for many years to come.

In general, there are two ways to increase crop production: increasing grain yield per unit area or expanding the area of cultivated land. Land consolidation projects (LCPs) contribute to both of these objectives in China. LCP in China usually include four components: land leveling, irrigation and drainage system construction, road construction and farmland shelter belt engineering measures. Between 2006 and 2010, LCPs were implemented on about 4 million hectares of land in China[7]. It is estimated that grain productivity per unit area increased by $10-20 \%$ on average after the implementation of LCPs. In addition, LCPs reduce the cost of grain production by $5-15 \%$ and thus improve farmers' livelihoods. LCP activities can also have strong effects on carbon emissions both due to emissions in the project construction process and due to changes in land use[8,9].

China has invested nearly 100 billion yuan annually in land consolidation projects, which have a strong effect on land use patterns and carbon emissions all over the country. However, less attention has been paid to the effects of LCPs on carbon emissions. Therefore, this paper aims to: (1) analyze land use changes due to LCP; (2) develop a method to assess the effects of LCPs on carbon emissions; and (3) assess carbon emissions attributable to LCP activities. 


\section{Experimental}

\section{Area and Data}

In this paper, two LCPs in the Taihang Piedmont in Hebei Province, China, are taken as case study areas. One LCP is in Julu $\left(114^{\circ} 50^{\prime}-115^{\circ} 14^{\prime} \mathrm{E}, 37^{\circ} 25^{\prime}-37^{\circ} 8^{\prime} \mathrm{N}\right)$ county and the other is in Baixiang $\left(114^{\circ} 36^{\prime}-114^{\circ} 47^{\prime} \mathrm{E}, 37^{\circ} 24^{\prime}-37^{\circ} 37^{\prime} \mathrm{N}\right)$ county (Fig. 1.). The total area of LCPs is $22.70 \mathrm{~km} 2$ in Julu and $1976.42 \mathrm{hm} 2$ in Baixiang.

Data on land use and the use of construction machinery derive from the "The Wang-Hu Town, Julu County, Land Consolidation Project Design Report”, "Gu Chengdian Town, Baixiang County Basic Farmland Consolidation Project Budget Statement" and "Wang-hu Town, Julu County Land Consolidation Project Budget Statement ". Other data are from The China Energy Statistical Yearbook” and “2006 IPCC Guidelines for National Greenhouse Gas Inventories[10]”.

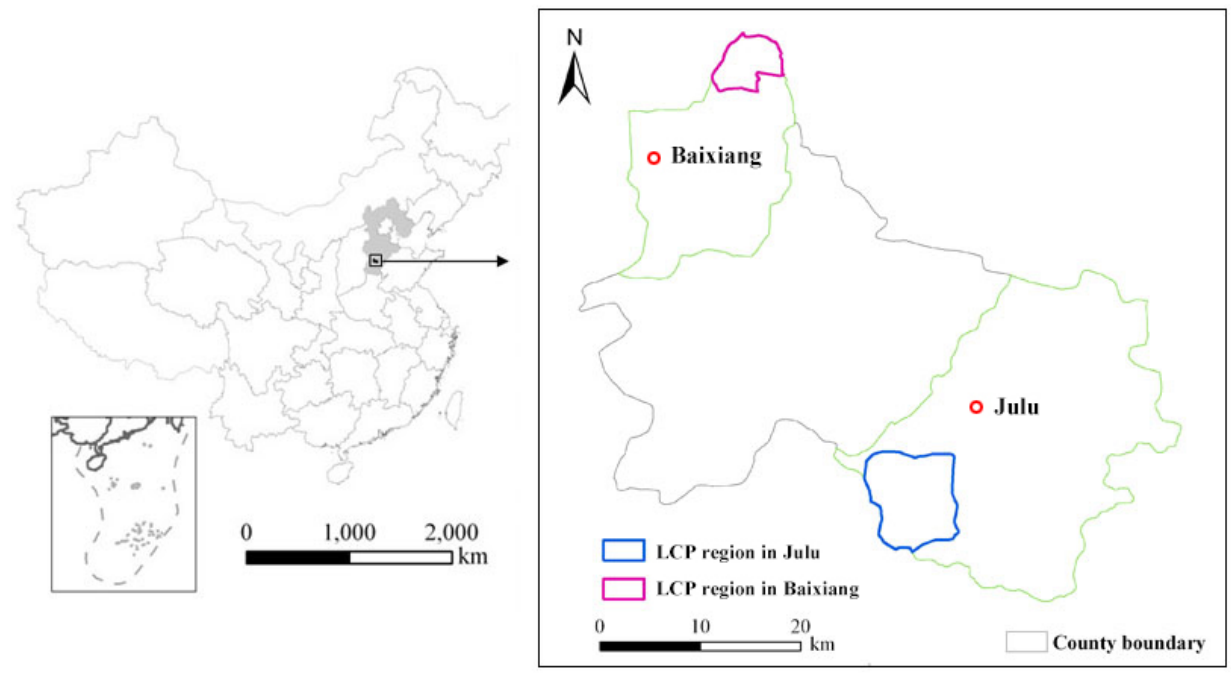

Fig. 1 The location of the LCP study areas in Julu and Baixiang counties

\section{Carbon Emissions in Land Consolidation}

In the LCP construction process, fossil fuels, such as gasoline and diesel, are burned due to the use of machinery, and represent a source of carbon emissions. In this study, we mainly consider the carbon emissions caused by energy consumption during the construction process. The calculation of the carbon emissions is as follows:

$$
E \mathrm{CO}_{2}=\mathrm{AD} \times \mathrm{EF}
$$

Where $\mathrm{ECO}_{2}$ is the amount of carbon emissions ( $\left.\mathrm{kg} \mathrm{C}\right) ; A D$ is the amount of fuel consumed in the LCP construction process; $E F$ is the emission factor for a given greenhouse gas by fuel and technology type, measured as the mass of GHG emitted per TJ on a net calorific basis (kg GHG/TJ).

According to the IPCC (2006), default carbon emission factors for gasoline and diesel are 2.26 $\mathrm{kgCO} 2 / \mathrm{L}$ and $2.73 \mathrm{kgCO} 2 / \mathrm{L}$ relatively. Combined with their density, the emission factor is converted into carbon emissions per unit mass $(\mathrm{kg} \mathrm{C} / \mathrm{Kg})$. Hence, the calculation of carbon emissions in the construction process of LCP is as follows:

$$
E c=T_{1} \times 0.85 \mathrm{kgC} / \mathrm{kg}+T_{2} \times 0.88 \mathrm{kgC} / \mathrm{kg}
$$

Where $\mathrm{E}_{\mathrm{C}}$ is the amount of carbon emissions $(\mathrm{kgC})$; $\mathrm{T}_{1}$ is the mass of gasoline consumed $(\mathrm{kg})$; $\mathrm{T}_{2}$ is the mass of diesel consumed $(\mathrm{kg})$.

We also assess emissions in terms of carbon emissions per unit of financial investment and the ratio of carbon emissions to investments:

$$
\begin{gathered}
M_{c}=C_{i} / M_{i} \\
M \%_{i}=\left(C_{i} / \sum C_{i}\right) /\left(M_{i} / \sum M_{i}\right)
\end{gathered}
$$


Where $M c$ is carbon emissions per unit of investment ( $\left.\mathrm{kgC} / 10^{4} \mathrm{yuan}\right) ; \mathrm{M}_{\mathrm{i}}$ is the ratio of the proportion of carbon emissions for a given LCP component to the proportion of total investments in that component; $C_{i}$ is the carbon emission of each individual engineering component in the LCP (tC), and $M_{i}$ is the financial investment in each engineering component in the LCP (10 ${ }^{4}$ yuan).

\section{Carbon Storage of Different Land Use Types}

In the study areas, land use types can be classified into ten categories: cultivated land, garden land, woodland, pasture land, other agricultural land, rural residential and industrial land, transport infrastructure land, water conservancy facility land, unused land and other land use types. Vegetation carbon density varies between different land use types. Considering that all land use types have different in biomass and carbon emissions, we adopt the average carbon density of different vegetation types in north China[11-13] to calculate the carbon storage of different land use types (Table 1.). Vegetation and soil carbon storage of different land uses are calculated as follows:

$$
V_{i}=C_{i} \times S_{i}
$$

Where $\mathrm{i}$ is an index of different land use types; $V_{i}$ is the carbon storage of land use type $\mathrm{i}(\mathrm{tC}) ; C_{i}$ is the carbon density of different vegetation /soil types in different land use types $\mathrm{i}\left(\mathrm{tC} / \mathrm{hm}^{2}\right)$; $\mathrm{Si}$ is the area of different vegetation /soil types in different land use types i $\left(\mathrm{hm}^{2}\right)$.

Table 1 Vegetation and soil carbon density of different land uses

\begin{tabular}{|c|c|c|c|c|c|}
\hline Land use types & $\begin{array}{c}\text { Vegetation } \\
\text { carbon } \\
\text { density } \\
/\left[\mathrm{tc}^{-} \mathrm{hm}^{-2}\right]\end{array}$ & $\begin{array}{c}\text { Soil } \\
\text { carbon } \\
\text { density } \\
/\left[\mathrm{tc}^{-2} \mathrm{hm}^{-}\right]\end{array}$ & Land use types & $\begin{array}{c}\text { Vegetation } \\
\text { carbon } \\
\text { density } \\
/\left[\mathrm{tc} \cdot \mathrm{hm}^{-2}\right]\end{array}$ & $\begin{array}{c}\text { Soil carbon } \\
\text { density } \\
/\left[\mathrm{tc} \cdot \mathrm{hm}^{-2}\right]\end{array}$ \\
\hline Cultivated land & 2.59 & 66.27 & $\begin{array}{c}\text { Rural residential and } \\
\text { industrial land }\end{array}$ & 11.86 & 71.59 \\
\hline Garden land & 98.91 & 54.77 & $\begin{array}{c}\text { Transport } \\
\text { infrastructure land }\end{array}$ & 10.55 & 25.36 \\
\hline Woodland & 65.5 & 44.23 & $\begin{array}{c}\text { Water conservancy } \\
\text { facility land }\end{array}$ & 6.64 & 40.64 \\
\hline Pasture land & 1.55 & 45.41 & Unused land & 1.5 & 55.45 \\
\hline $\begin{array}{c}\text { Other } \\
\text { agricultural land }\end{array}$ & 1.59 & 62.95 & Other land & 1.41 & 68.82 \\
\hline
\end{tabular}

\section{Results and Discussion}

According to “The Wang-hu Town, Julu County, LCP Design Report”, after LCP implementation, cultivated land area will reach $1820.06 \mathrm{hm}^{2}$ (Table 2.). The newly created irrigated land area is $1175.23 \mathrm{hm}^{2}$. The newly created cultivated land area is $89.13 \mathrm{hm}^{2}$, accounting for $3.93 \%$ of the total cultivated land area. The increase in cultivated land is mainly derived from garden land which covers $56.77 \mathrm{~km}^{2}$. Conversion to water conservancy facility land and grassland covered $24.97 \mathrm{hm}^{2}$ and $7.39 \mathrm{hm}^{2}$, respectively. At the same time, $4.16 \mathrm{hm}^{2}$ of water conservancy facility land was converted to transport infrastructure land.

According to the Guchengdian Town, Baixiang County Basic Farm LCP Detailed Design Report, cultivated land increased by $97.02 \mathrm{hm}^{2}$ (Table 3.), accounting for $4.91 \%$ of the total cultivated land area.

Our results reveal that there is not much difference in the increase in the area of cultivated land between the projects in Julu and Baixiang, but there is a difference in the carbon stock changes in the two project areas. In Julu, the increased area of cultivated land was mainly due to conversion from garden land, which has a much higher carbon density $\left(153.68 \mathrm{tC} / \mathrm{hm}^{2}\right)$ than that of cultivated land $\left(68.86 \mathrm{tC} / \mathrm{hm}^{2}\right)$. The increase in cultivated land in the Baixiang project area was mainly due to conversion from unused land and other agricultural land, which has a lower carbon density $\left(56.95 \mathrm{tC} / \mathrm{hm}^{2}\right)$ than that of cultivated land. 
Table 2 Change in land use in Julu LCP $\left[\mathrm{hm}^{2}\right]$

\begin{tabular}{|l|l|l|l|l|}
\hline Land use types & $\begin{array}{l}\text { Before } \\
\text { project }\end{array}$ & $\begin{array}{l}\text { After } \\
\text { project }\end{array}$ & $\begin{array}{l}\text { Change in } \\
\text { area }\end{array}$ & $\begin{array}{l}\text { Carbon storage } \\
\text { [tC] }\end{array}$ \\
\hline Cultivated land & 1730.93 & 1820.06 & 89.13 & 6137.49 \\
\hline Garden land & 60.03 & 3.27 & -56.77 & -8722.88 \\
\hline Woodland & 8.14 & 8.14 & 0.00 & 0.00 \\
\hline Pasture land & 70.46 & 63.07 & -7.39 & -347.03 \\
\hline $\begin{array}{l}\text { Rural residential and industrial } \\
\text { land }\end{array}$ & 228.13 & 228.13 & 0.00 & 0.00 \\
\hline Transport infrastructure land & 60.80 & 64.96 & 4.16 & 149.39 \\
\hline Water conservancy facility land & 104.85 & 75.72 & -29.13 & -1377.27 \\
\hline Other land & 6.75 & 6.75 & 0.00 & 0.00 \\
\hline Total & 2270.09 & 2270.09 & 0.00 & -4160.30 \\
\hline
\end{tabular}

Table 3. Change in land use in Baixiang LCP $\left[\mathrm{hm}^{2}\right]$

\begin{tabular}{|l|l|l|l|l|}
\hline Land use types & $\begin{array}{l}\text { Before } \\
\text { project }\end{array}$ & $\begin{array}{l}\text { After } \\
\text { project }\end{array}$ & $\begin{array}{l}\text { Change in } \\
\text { area }\end{array}$ & $\begin{array}{l}\text { Carbon storage } \\
{[\mathrm{tC}]}\end{array}$ \\
\hline Cultivated land & 1840.70 & 1937.72 & 97.02 & 6680.80 \\
\hline Other agricultural land & 79.57 & 38.70 & -40.87 & -2637.75 \\
\hline $\begin{array}{l}\text { Rural residential and } \\
\text { industrial land }\end{array}$ & 3.65 & 0.00 & -3.65 & -304.59 \\
\hline $\begin{array}{l}\text { Unused land(unused } \\
\text { grassland) }\end{array}$ & 52.50 & 0.00 & -52.50 & -2989.88 \\
\hline Total & 1976.42 & 1976.42 & 0.00 & 748.58 \\
\hline
\end{tabular}

\section{Summary}

Land consolidation is an effective way to optimize the overall structure of land use. In China, it is accomplished primarily through land leveling engineering, irrigation and drainage engineering, rural road engineering and farmland protection measures.

The following recommendations to decrease carbon emissions from LCP activities can be made: (1) Efforts should be taken to decrease the volume of excavation and fill in land leveling components, to maintain the original topography to the extent that this does not hinder post-project land use and farming; (2) Efforts should be made to reduce the consumption of fossil fuels and use cleaner fuels to decrease carbon emissions in the process of construction. Specifically, ways to change the fuel mix, or use alternative energy sources such as natural gas or electricity should be investigated; (3) This study showed that effects on carbon stocks mainly depend on the types of land involved in land use conversions. Guidance should be developed to discourage conversion of land use types with high carbon stocks.

Carbon emissions include both direct and indirect carbon emissions. Direct carbon emissions derive from fossil fuel use in land leveling engineering, irrigation and drainage engineering, road engineering construction and other processes during project implementation. Indirect carbon emissions are caused in the manufacture of construction materials, such as precast concrete boards, PVC pipes, tree seedlings, etc. as well as their transportation process. In this paper, we mainly consider direct carbon emissions, Calculation of indirect carbon emissions due to LCP project processes is a key direction for future research.

\section{References}

[1] JAYATILLEKE S.BANDARA, YIYONG CAI: The Impact of Climate Change on Food Crop Productivity, Food prices and Food Security in South Asia. Economic Analysis and Policy, 44(4), 451(2014).

[2] DANIEL P. BEBBER, SARAH J. GURR: Crop-destroying Fungal and Oomycete Pathogens Challenge Food Security. FUNGAL GENET BIOL, 74, 62(2015). 
[3] GIACOMO BRANCA, LESLIE LIPPER, NANCY McCARTHY MARIA CHRISTINA JOLEJOLE: Food Security, Climate Change, and Sustainable Land Management. a Review. AGRON SUSTAIN DEV, 33(4), 635(2013).

[4] HUILI GONG, DAN MENG, XIAOJUAN LI, FENG ZHU: Soil Degradation and Food Security Coupled with Global Climate Change in Northeastern China. CHINESE GEOGR SCI, 23(5), 562(2013).

[5] ZHIHAO QIN, HUAJUN TANG, WENJUAN LI, HAO ZHANG, SHUHE ZHAO, QIANG WANG: Modelling impact of agro-drought on grain production in China. International Journal of Disaster Risk Reduction, 7, 109(2014).

[6] RöTTER R.P, HöHN J.G, FRONZEK S: Projections of Climate Change Impacts on Crop Production: A Global and a Nordic Perspective. Acta Agriculturae Scandinavica (Section A ), 62(4), 166(2012).

[7] J WANG, Z LI, Z BAI, Z JU, G WANG: Progress and Prospect of Ecological Environment Impact of Land Consolidation. Transactions of the Chinese Society of Agricultural Engineering, 27(13), 340(2011).

[8] R. A. HOUGHTON: Revised Estimates of the Annual Net Flux of Carbon to the Atmosphere from Changes in Land Use and Land Management 1850-2000. Tellus, 55B, 378(2003).

[9] LEVY P.E, FRIEND A.D, White A, CANNELL M.G.R: The Influence of Land Use Change On Global-Scale Fluxes of Carbon from Terrestrial Ecosystems. Climatic Change, 67(2), 185(2004).

[10] IPCC. IPCC Guidelines for National Greenhouse Gas Inventories . Institute for Global Environmental Strategies, Hayama, Japan, 2006.

[11] LI KEYANG, WANG SHAOQIANG, CAO MINGKUI: Vegetation and Soil Carbon Storage in China. Science in China (Series D), 33(1), 49(2003).

[12] WANG SHAOQIANG, ZHOU CHENGHUI, LUO CHENGWEN: Studying Carbon Storage Spatial Distribution of Terrestrial Natural Vegetation in China. PROGRESS IN GEOGRAPHY, 18(3), 238(1999).

[13] LI SUIMIN, LUAN WENLOU, SONG ZEFENG, CUI XINGTAO, MA ZHONGSHE: An Estimation of Oil Organic Carbon Reserves in the Southern Plain of Hebei Province. GEOLOGY IN CHINA, 37(2), 525 (2010).

[14] 